\title{
The Effectiveness of Using Differentiated Education Strategy in Developing the Literacy Skills of the Seventh Grade Students in English at Public Schools in Jordan
}

\author{
Dr. Mona Smadi \\ Dr. Amaal Al Masri \\ Assistant Professor \\ Princess Alia University College \\ Al Balqa Applied University \\ Amman, Jordan
}

\begin{abstract}
The study aimed to identify the effectiveness of differentiated education strategy in the development of literacy skills of seventh grade students in English at public schools in Jordan. The problem of the study was identified in the following main question: What is the effectiveness of the differentiated education strategy in developing the reading and writing skills of seventh grade students in English Language? In this study, the researchers used the experimental method; the study population consisted of seventh grade students in the public schools at Wadi AlSeer directorate of education during the academic year 2016/2017. The study sample consisted of (140) male and female seventh grade students at Marj Al-Hamam Basic School for Girls and Al Baraa Secondary School for boys, distributed to two groups: one experimental (70) students and control (70) students. The study tools were a test to measure literacy skills and the researchers adjusted the independent variables, then the reading and writing test was applied to a pilot sample from outside the study sample. After the experiment was carried out for (5) weeks, with (10) periods weekly, the two groups were subjected to reading and written tests. The researchers used the T-test for two independent samples to determine the effect of the differences between the two groups. The results were as follows: There were statistically significant differences at $(\alpha=0.05)$ between the average of the students of the experimental group (who are studying through the differentiated education) and the average score of the students in the control group (who study through regular education), in favor of the experimental group. The study came out with some recommendations.
\end{abstract}

\section{Keywords: Differentiated Education Strategy, Literacy Skills, Seventh Grade Students}

\section{Introduction}

People differed in defining the nature of education as a way of thinking in education Tomlinson (2005), Campbell (2008) or teaching theory (Campbell 2005), and learning theory of Kojek et al. (2008) or Teaching System Attiyah (2009) or the Teaching Method Ziebell (2004) or the strategy of teaching slaves and Abu Samaid (2009) (Drapeau 2002) and Dravio (2011) and the researcher agrees with the latter opinion that the differentiated education is considered teaching strategy (Gangi and Ganji, 2010) "The teaching strategy reflects the long teaching plan Term positions, used to teach a course or unit of study. It is more general and comprehensive than approach, where the strategy includes more than a teaching method to achieve long-term goals, which need time, sequence and integration of experiences". The teaching of English in schools in Jordan still needs a lot of development and modernization, especially at the level of teaching strategies used in education. The reasons for this are many, including that learning foreign languages is important for the individual and the community. By learning foreign languages, the individual gains many benefits. Knowing the foreign language helps the individual to be flexible in thinking and expanding his perception. The benefits at the community level are to empower and define the customs and traditions of the peoples of the world, creating a society that is receptive or understanding to other peoples. In fact, learning foreign languages is not a luxury but a necessity and an essential requirement in the era of globalization and the information and technology revolution. This is because it is an important means of transferring knowledge and science from one nation to another and a tool for creating cultural cross-cultural exchange among the peoples of the world (Huleisi, 2011) 


\section{The Problem of the Study}

Based on modern trends in education and calling for the need to provide education to all members of society taking into account the difference between them. Recognizing the importance of teaching English at the primary level, which in turn is the basis and foundation for the rest of the other levels of education; it requires the provision of all means to achieve this trend. This includes caring for and choosing the best educational strategies that help students to master the basics of this language and prepare them to become more capable in the next stages. In view of the Ministry of Education's approach to the implementation of modern educational strategies, which are centered around the learner and take into account the tendencies and abilities and previous experiences, while taking into account at the same time differentiation and differences between students. Therefore, the researcher will work on experimenting with an educational strategy which is one of the latest teaching strategies that are concerned with the differentiation and differences among students.

\section{Questions of the Study}

1. What are the reading skills that $7^{\text {th }}$ grade students should have?

2. What are the writing skills that 7 th grade students should have?

3. Are there statistically significant differences at $(\alpha=0.05)$ between the mean scores of the experimental group and the mean of the control group in the post-test of reading skills?

4. Are there statistically significant differences at $(\alpha=0.05)$ between the mean scores of the experimental group and the mean of the control group in the post-test of writing skills?

\section{Definition of Terms}

Differentiated learning: Differentiation means tailoring instruction to meet individual needs. Whether teachers differentiate content, process, products, or the learning environment, the use of ongoing assessment and flexible grouping makes this a successful approach to instruction. Teaching strategy: Teaching strategies refer to methods used to help students learn the desired course contents and be able to develop achievable goals in the future. Teaching strategies identify the different available learning methods to enable them to develop the right strategy to deal with the target group identified.

\section{Previous Studies}

Al-Burini (2011) conducted a study to investigate the teachers' experiences and attitudes toward the application of differentiated teaching methods through an exploratory study on the reality of education in the United Arab Emirates. Al-Burini discussed the importance of diversification in teaching methods in order to reach all students in the same class according to their abilities and level, especially in light of the ministry's focus on integrating people with special needs. Prior to this, it is necessary to identify learners' learning patterns, interests and attitudes before starting the teaching process. The theory of differentiated education depends on the idea of adapting content and methods to suit the real level of students at all levels and in light of their problems so that strategies are adopted to help achieve the goals without frustrating the outstanding or ignore the weak level, and avoid the common practice of the teacher, which often focuses on the student average level, for all is guaranteed by law, legislation and policies of the Ministry of Education in the State.

The study measures the influence of teachers' convictions, their preconceived ideas, and their level of training in the success of their differentiated teaching strategies. The study deals with the most important obstacles and problems faced by the teacher in order to achieve effective learning that achieves the desired goals.

Hubard (2009) conducted a study entitled "Impact of Differentiated Education on English Language Learners at the Secondary Level with Emphasis on the Sex of the Learner". This study was conducted to determine the effectiveness of the use of differentiated learning on English language learners in the secondary stage in one of the English language courses. The study dealt with the following questions: What are the teaching strategies that affect the learners of English language and in general the linguistic development? Also, what are the effective teaching practices to develop grammar skills, and how does the learner's gender variable and preferred learning style affect the development of English language learning? The purpose of this study was to determine whether teacher-centered teaching strategies affect English learners and their linguistic development compared to learnercentered teaching strategies. The researcher used the field survey as a study tool. The study sample consisted of two groups of high school students. The two groups alternated these teaching strategies and conducted the survey as a means of measuring students' attitudes towards the development of their language as well as to assess their preferred learning style. The assessment of responses took into account gender. 
The data included a weekly assessment of student grades and a link to this in the teaching method. The results of the study indicated that differentiated learning strategies affect the linguistic development of English learners. The results also indicated that the student-centered teaching method has a positive impact on student performance. I have demonstrated that there is a link between students' performance and the teaching strategy used and the gender of the learner. Swift (2009) conducted a study entitled "The Effect of Differentiated Education in Social Studies on Student Performance". The purpose of this study was to determine whether there was an impact of differential learning on student performance. The study sample consisted of two groups of third grade students for more than two years. The first group studied social studies through the course book and took a test at the end of each unit. While the second group was studied using highly differential learning, and the students had the choice in the evaluation process between entering the test or working on a final project. In the final report, the scores of students in the two groups were compared to determine whether there was improvement in grades when differentiated education was used. Students' grades improved when differentiated learning was used, and students were free to choose the method of assessment.

Hobson (2008) conducted a study (Analysis of differentiation strategies) used by teachers in middle schools within multi-capacity classrooms. This study examined the differentiation strategies used by middle school teachers in various multi-capacity classrooms. Quantitative and qualitative data were collected by means of questionnaire and observation within the classroom. The study analyzed the frequency with which middle school teachers implement their differentiation within their classrooms. It also analyzes educational or contextual factors, if there is an impact on the method of repetition when using these strategies in order to meet the needs of different learners. The study was conducted in a middle school in South East Carolina. The teachers asked questions about how often they used to distinguish in their classes, and watched them in their classes as they taught teaching materials.

The results of the study indicated that there are two sets of teachers: some of them uses differentiate learning but others use it less frequently. The results also indicate that there are factors such as years of experience in teaching and development. The skills of faculty members have a negligible effect on the number of times teachers implement strategies, differentiation within their classrooms.

\section{Design and Methodology}

\section{Study Approach}

The researcher used the experimental approach which is "the method in which the variables affecting a phenomenon are controlled except for one variable that the researchers adapt and change in order to determine and measure its effect on the phenomenon in question, where the researchers subjected the test in this study to seventh grade students. The experimental approach is the most appropriate for the subject under study. The design of the two experimental and control groups has been followed so that the experimental group was taught through using differentiated learning strategy, while the control group received a regular teaching.

\section{Population of the Study}

The study population consisted of seventh grade students in the public schools at Wadi Al-Seer directorate of education during the academic year 2016/2017.

\section{Sample of the Study}

The study sample consisted of (140) male and female seventh grade students at Marj Al-Hamam Basic School for Girls and Al Baraa Secondary School for boys, distributed to two groups: one experimental (70) students and control (70) students.

\section{Tool of the Study}

The study tool was a test to measure literacy skills and the researchers adjusted the independent variables, then the reading and writing test was applied to a pilot sample from outside the study sample. After the experiment was carried out for (5) weeks, with (10) periods weekly, the two groups were subjected to reading and written tests. The researchers used the T- test for two independent samples to determine the effect of the differences between the two groups.

\section{Validity of the test}

\section{a.Arbitrators validity}


The test was presented in its preliminary form to a group of specialists in the field of curriculum and teaching methods. It was also presented to a group of experienced teachers to express their opinions on the test questions in terms of formulating the questions, their clarity and suitability to the students' level, the possibility of deletion and addition, Some questions have been modified and formulated to reach the final form.

\section{b.Validity of the internal consistency}

The validity of the internal consistency of the test was verified by applying the test to a sample of (20) students from outside the study sample. Pearson correlation coefficient was calculated between the skills of each test question and its total grade, Pearson correlation coefficients were calculated between each axis of the test as a whole, a correlation coefficient was also found for each sub-question of the test questions and its axis. The results showed that the test was valid.

\section{Reliability of the test}

The researcher verified the stability of the test applied to the survey sample in two ways:

- Split Half Method

- Alpha Cronbach equation.

The results showed that the test was valid

\section{Statistical Methods:}

To verify the hypotheses, the researcher used the statistical program (SPSS) as follows:

1.To calculate the validity of the study tools, the researcher used the following statistical treatments:

- Internal Consistency

2. To calculate the reliability of the study tools, the researcher used the following statistical treatments:

- Cronbache Alfa equation

- Split Half Method

3.Using "T-test" for the values adopted (within the groups), and test "T-test" for the values not approved Independent between (between groups).

\section{Results of the Study and its Discussion}

In this section, the researcher began a detailed presentation of the results achieved through the application of the study tool, in addition to explaining and discussing the results reached by answering the study questions and verifying the hypothesis of the study:

Results of the First Questions: What are the reading skills that 7th grade students should have?

This study revealed the effectiveness of using differentiated learning in the development of some of the reading skills of the seventh grade students. In light of this, the researchers studied the educational literature and some previous research on the development of reading skills in the basic stage. The researchers studied the content of the English language book for the seventh grade, in the first and second semesters, according to the curriculum, and the researchers identified some reading skills that must be developed among the seventh grade students, hence, the researchers sought to explore the opinions of the specialized experts and the educational supervisors in the field of English language, taking the opinions of some teachers, principals of English teachers and teachers of the basic stage. The researchers found that the most skills that must be developed by the seventh grade students as follows:

1.Reading with a purpose, knowing when it's important to understand every detail and when she can read quickly for pure enjoyment

2. Reading selectively, scanning chapter headings and introductory sentences to find necessary information

3. Getting below the surface of facts on the page and evaluating critically

4. Using knowledge of prefixes, suffixes, and base words to expand

5.Mastering the vocabulary of different content areas

6. Reading fast enough to do homework in a reasonable amount of time

7.Reading for pleasure

8. Skimming a chapter in a textbook to form an overall impression

Results of the Second Question: What are the writing skills that 7th grade students should have?

This study revealed the effectiveness of using differentiated learning in the development of some of the writing skills of the seventh grade students. 
In light of this, the researchers studied the educational literature and some previous research on the development of writing skills in the basic stage. The researchers studied the content of the English language book for the seventh grade, in the first and second semesters, according to the curriculum, and the researchers identified some writing skills that must be developed among the seventh grade students, hence, the researchers sought to explore the opinions of the specialized experts and the educational supervisors in the field of English language, taking the opinions of some teachers, principals of English teachers and teachers of the basic stage. The researchers found that the most writing skills that must be developed by the seventh grade students as follows:

1.Write in complete sentences, varying the types such as compound and complex sentences

2.Place modifiers properly and use the active voice

3. Use regular and irregular verb tenses appropriately and consistently such as present, past, future, perfect, and progressive.

4.Use adjectives (comparative and superlative forms) and adverbs appropriately to make writing vivid or precise.

5.Use correct punctuation for clauses such as in dependent and independent clauses and participles and participial phrases.

6. Write with increasing accuracy when using apostrophes in contractions (won't), possessives ( Smith's) and plural possessives (birds')

7.Capitalize correctly to clarify and enhance meaning

8. Write fluidly and legibly in cursive or manuscript as appropriate

Results of the Third Question: Are there statistically significant differences at $(\alpha=0.05)$ between the mean scores of the experimental group and the mean of the control group in the post-test of literacy skills? To answer this question, the researcher formulated the following zero hypothesis: "There are no statistically significant differences at $(\alpha=0.05)$ between the mean scores of the experimental group and the average score of the control group in the post-test of reading skills. To test this hypothesis, the researcher used the "T-test" to calculate the significance of the differences between two independent groups in order to identify the differences between the average scores of the experimental and control groups on the reading skill scale after the implementation of the program. The following table clarifies this

Table (1): The significance of the differences between the average scores of the students of the experimental and control groups in post-test of reading skill

\begin{tabular}{|c|c|c|c|c|c|c|}
\hline Reading Skills & Group & $\mathbf{N}$ & Mean & SD & $\begin{array}{l}\text { T } \\
\text { value }\end{array}$ & Sig \\
\hline \multirow{2}{*}{$\begin{array}{l}\text { Reading with a purpose, knowing when it's important to } \\
\text { understand every detail and when she can read quickly for } \\
\text { pure enjoyment }\end{array}$} & Control & 70 & 0.83 & 0.71 & \multirow[b]{2}{*}{9.73} & \multirow[b]{2}{*}{0.000} \\
\hline & Experimental & 70 & 2.6 & 0.81 & & \\
\hline \multirow{2}{*}{$\begin{array}{l}\text { Reading selectively, scanning chapter headings and } \\
\text { introductory sentences to find necessary information }\end{array}$} & Control & 70 & 0.66 & 0.76 & \multirow[b]{2}{*}{9.03} & \multirow[b]{2}{*}{0.000} \\
\hline & Experimental & 70 & 2.4 & 0.85 & & \\
\hline \multirow{2}{*}{$\begin{array}{l}\text { Getting below the surface of facts on the page and } \\
\text { evaluating critically }\end{array}$} & Control & 70 & 1.26 & 0.74 & \multirow[b]{2}{*}{9,92} & \multirow[b]{2}{*}{0.000} \\
\hline & Experimental & 70 & 3.14 & 0.85 & & \\
\hline \multirow{2}{*}{$\begin{array}{l}\text { Using knowledge of prefixes, suffixes, and base words to } \\
\text { expand }\end{array}$} & Control & 70 & 1.26 & 1.24 & \multirow[b]{2}{*}{8,92} & \multirow[b]{2}{*}{0.000} \\
\hline & Experimental & 70 & 3.37 & 0.65 & & \\
\hline \multirow[t]{2}{*}{ Mastering the vocabulary of different content areas } & Control & 70 & 0.77 & 0.88 & \multirow[b]{2}{*}{10.2} & \multirow[b]{2}{*}{0.000} \\
\hline & Experimental & 70 & 2.66 & 0.64 & & \\
\hline \multirow{2}{*}{$\begin{array}{l}\text { Reading fast enough to do homework in a reasonable } \\
\text { amount of time }\end{array}$} & Control & 70 & 0.89 & 0.87 & \multirow[b]{2}{*}{4.99} & \multirow[b]{2}{*}{0.000} \\
\hline & Experimental & 70 & 1.71 & 0.46 & & \\
\hline \multirow[t]{2}{*}{ Reading for pleasure } & Control & 70 & 2.06 & 1.45 & \multirow[b]{2}{*}{21.3} & \multirow[b]{2}{*}{0.000} \\
\hline & Experimental & 70 & 8.03 & 0.79 & & \\
\hline \multirow{2}{*}{$\begin{array}{l}\text { Skimming a chapter in a textbook to form an overall } \\
\text { impression }\end{array}$} & Control & 70 & 0.74 & 0.85 & \multirow[b]{2}{*}{6.38} & \multirow[b]{2}{*}{0.000} \\
\hline & Experimental & 70 & 1.77 & 0.43 & & \\
\hline \multirow[t]{2}{*}{ Overall degree } & Control & 70 & 8.46 & 2.96 & \multirow[b]{2}{*}{28.7} & \multirow[b]{2}{*}{0.000} \\
\hline & Experimental & 70 & 25.7 & 1.95 & & \\
\hline
\end{tabular}

* The value of the tabulated " $t$ " at the degree of freedom (68) and at the level of significance $(\alpha=0.05)=1.69$.

* The value of the tabulated " $t$ " at the degree of freedom (68) and at the level of significance $(\alpha=0.01)=2.56$. 
Table (11) shows that the value of calculated "t" in reading skill is greater than the tabulated value (2.83) at the degree of freedom of 70-2 = 68 and the level of significance (0.01). This indicates that there are statistically significant differences between the experimental group and the control group. The differences were in favor of the experimental group.

Results of the Fourth Question: Are there statistically significant differences at $(\alpha=0.05)$ between the mean scores of the experimental group and the mean of the control group in the post-test of writing skills?

To answer this question, the researcher formulated the following zero hypothesis: "There were no statistically significant differences at (0.05) between the average mean of the experimental group and the mean of the control group in the post-test of writing skills. To test this hypothesis, the researcher used the " $t$ " test to calculate the significance of the differences between two independent groups in order to identify the differences between the average scores of the experimental and control groups on the writing skill scale after the implementation of the program, and the following table illustrates this:

Table (2): The significance of the differences between the average scores of the students in the experimental and control groups in post-test of the writing skill

\begin{tabular}{|c|c|c|c|c|c|c|}
\hline Reading Skills & Group & $\mathrm{N}$ & Mean & SD & T value & Sig \\
\hline \multirow{2}{*}{$\begin{array}{l}\text { Write in complete sentences, varying the types such as } \\
\text { compound and complex sentences }\end{array}$} & Control & 70 & 0.51 & 0.61 & \multirow[b]{2}{*}{17.4} & \multirow[b]{2}{*}{0.000} \\
\hline & Experimental & 70 & 2.74 & 0.44 & & \\
\hline \multirow[t]{2}{*}{ Place modifiers properly and use the active voice } & Control & 70 & 1.34 & 0.68 & \multirow[b]{2}{*}{2.67} & \multirow[b]{2}{*}{0.000} \\
\hline & Experimental & 70 & 1.51 & 0.51 & & \\
\hline \multirow{2}{*}{$\begin{array}{l}\text { Use regular and irregular verb tenses appropriately and } \\
\text { consistently such as present, past, future, perfect, and } \\
\text { progressive. }\end{array}$} & Control & 70 & 1.43 & 0.92 & \multirow[b]{2}{*}{6.65} & \multirow[b]{2}{*}{0.000} \\
\hline & Experimental & 70 & 2.63 & 0.55 & & \\
\hline \multirow{2}{*}{$\begin{array}{l}\text { Use adjectives (comparative and superlative forms) and } \\
\text { adverbs appropriately to make writing vivid or precise. }\end{array}$} & Control & 70 & 0.89 & 0.83 & \multirow[b]{2}{*}{6.62} & \multirow[b]{2}{*}{0.000} \\
\hline & Experimental & 70 & 1.89 & 0.32 & & \\
\hline \multirow{2}{*}{$\begin{array}{l}\text { Use correct punctuation for clauses such as in dependent } \\
\text { and independent clauses and participles and participial } \\
\text { phrases. }\end{array}$} & Control & 70 & 1.71 & 1.05 & \multirow[b]{2}{*}{8.89} & \multirow[b]{2}{*}{0.000} \\
\hline & Experimental & 70 & 3.6 & 0.69 & & \\
\hline \multirow{2}{*}{$\begin{array}{l}\text { Write with increasing accuracy when using apostrophes in } \\
\text { contractions (won't), possessives ( Smith's) and plural } \\
\text { possessives (birds') }\end{array}$} & Control & 70 & 0.86 & 0.81 & \multirow[b]{2}{*}{6.69} & \multirow[b]{2}{*}{0.000} \\
\hline & Experimental & 70 & 1.86 & 0.36 & & \\
\hline \multirow[t]{2}{*}{ Capitalize correctly to clarify and enhance meaning } & Control & 70 & 0.6 & 0.65 & \multirow[b]{2}{*}{8.91} & \multirow[b]{2}{*}{0.000} \\
\hline & Experimental & 70 & 1.77 & 0.43 & & \\
\hline \multirow{2}{*}{$\begin{array}{l}\text { Write fluidly and legibly in cursive or manuscript as } \\
\text { appropriate }\end{array}$} & Control & 70 & 0.6 & 0.69 & \multirow[b]{2}{*}{8.50} & \multirow[b]{2}{*}{0.000} \\
\hline & Experimental & 70 & 1.77 & 0.43 & & \\
\hline \multirow[b]{2}{*}{ Overall degree } & Control & 70 & 7.94 & 2.61 & \multirow[b]{2}{*}{20.71} & \multirow[b]{2}{*}{0.000} \\
\hline & Experimental & 70 & 17.8 & 1.26 & & \\
\hline
\end{tabular}

* The value of the tabulated " $t$ " at the degree of freedom (68) and at the level of significance $(\alpha=0.05)=1.69$.

* The value of the tabulated " $t$ " at the degree of freedom (68) and at the level of significance $(\alpha=0.01)=2.56$.

Table (11) shows that the value of calculated "t" in writing skill is greater than the tabulated value (2.56) at the degree of freedom of $70-2=68$ and the level of significance (0.01). This indicates that there are statistically significant differences between the experimental group and the control group. The differences were in favor of the experimental group. The results of the present study agreed with the results of a number of studies on the effectiveness of using the differentiated learning strategy in the basic stage, it also agreed with the result, there are statistically significant differences between the experimental group and the experimental group in favor of the experimental group. This may be attributed to the fact that the use of differentiated education has contributed to the effective development of reading and writing skills among students in the experimental group, as well as the interaction of students with various activities and their readiness to learn using new teaching strategies. The speed of solving students for activities after the implementation of different methods and means, which indicates the importance and necessity of diversification in the strategies and methods of teaching used for students of this stage, and students have been eager to wait for the time of implementation of the period.

The results of the hypothesis can be explained by the following: 
- Suitability of the strategy for the students' levels. As confirmed by the arbitrators.

- Attract students' attention to the strategy, which had a significant impact, in revealing the extent of reading and writing students of the skills properly.

- The active participation of students in reading skills to be developed.

- Renewal in the classroom environment during the enthusiasm of students to learn reading and writing skills with strong motivation.

- The researcher applied the proposed strategy herself because of her knowledge of the characteristics of her students.

\section{Recommendations}

Based on the findings of the study, the researcher recommends the following:

- Using a distinct learning strategy in the development of reading and writing skills in English.

- Taking care of the development of reading and writing skills in the English language in the basic stage.

- Taking care of teacher training and qualification, through educational bulletins, training courses, in order to familiarize them with the basics of teaching reading and writing skills and how to employ the use of differentiated education.

\section{References}

Ankrum, Julie W ( 2006 ) Differentiated Reading Instruction in One Exemplary Teachers Classroom : A Case Study . Unpublished thesis EdD . University of Pittsburg .

Gangi , Suzanna (2011) Differentiated Instruction Using Multiple Intelligences in the Elementary School Classroom . Unpublished master's thesis . University of Wisconsin-Stout

Abu - Gararah , Ali Hamzah (2005) Teaching English as A Foreign language, Riyadh : Tawbah Library .

Affholder, L. P. (2003). Differentiated Instruction in Inclusive Elementary Classrooms - published thesis EdD. University of Kansas, Kansas.

AL- Hajailan ,Talal A (2007) Teaching English in Saudi Arabia, Riyadh : Al-Dar AL-Sawlatia .

Bantis ,Alexandros . M (2008) Using Task Based Instruction To Provide Differentiated Instruction For English Language Learners .Unpublished master's thesis . University of South California .

Blaz , D (2006) Differentiated Instruction A Guide for Foreign Language Teachers , New York : Eye on Education, Inc .

Burns, J.P. (2004). An Analysis of the Implementation of Differentiated Instruction In A Middle school An High school and The Effects of Implementation on Curriculum Content And Student Achievement . Published thesis PhD Seton Hall university .

Campbell , B (2008) Handbook of differentiated Instruction Using the Multiple Intelligences lesson Plans and More, Boston : Pearson Education, Inc .

Campbell , Michael(1978) . Language and Situation : Language Varieties and Their Social Context . London ;Routledge , and KeganPaul ,

Drapeau , P (2004) Differentiated Instruction Making It Work, New York : Scholastic .

Heacox , Diane (2001) Differentiating Instruction in the Regular Classroom; How to reach and teach ALL learners, grades 3-12 by. Free Spirit Publishing.

Hodge, P.H. (1997).An Analysis of the Impact of a Prescribed Staff development program in differentiated instruction on student achievement and the attitudes of teachers and parents toward that instruction., Published thesis - EdD. University of Alabama.

Hubbard, Daniel. A. (2009).The Impact of Different Tiered Instruction for English Language Learners at the secondary level with a Focus on Gender., unpublished thesis M.A California State university.

Jakobovits, Leon A . Readings in the Psychology of Language .Engel, Wood Cliffs , N .J . : Prenttice ,Hall ,1967. Rivers, Wilga M ( 1980) Teaching Foreign Language Skills . $2^{\text {nd }}$ edition, USA : The University of Chicago press .

Swift .M.K (2009).The Effect Differentiated Instruction in social Student Performance . Unpublished master's thesis, University of Wisconsin-Stout, united States of America.

Tomlinson, c (2001) How to Differentiate Instruction In Mixed -ability Classroom, Virginia : ASCD . 